\title{
Key signaling nodes in mammary gland development and cancer: Smad signal integration in epithelial cell plasticity
}

Anders Sundqvist', Peter ten Dijke ${ }^{1,2}$ and Hans van Dam ${ }^{* 1,2}$

\begin{abstract}
Smad proteins are the key intermediates of transforming growth factor-beta (TGF- $\beta$ ) signaling during development and in tissue homeostasis. Pertubations in TGF- $\beta /$ Smad signaling have been implicated in cancer and other diseases. In the cell nucleus, Smad complexes trigger cell type- and context-specific transcriptional programs, thereby transmitting and integrating signals from a variety of ligands of the TGF- $\beta$ superfamily and other stimuli in the cell microenvironment. The actual transcriptional and biological outcome of Smad activation critically depends on the genomic integrity and the modification state of genome and chromatin of the cell. The cytoplasmic and nuclear Smads can also modulate the activity of other signal transducers and enzymes such as microRNA-processing factors. In the case of breast cancer, the role of Smads in epithelial plasticity, tumor-stroma interactions, invasion, and metastasis seems of particular importance.
\end{abstract}

\section{Introduction}

As the key intermediates of canonical transforming growth factor-beta (TGF- $\beta$ ) signaling, Smad proteins play crucial roles in the determination of cell fate of multicellular organisms. These proteins are vertebrate homologs of the Drosophila protein MAD (mothers against decapentaplegic) and the Caenorhabditis elegans protein SMA (small), which were identified by genetic screens. The Smad name is a combination of the two [1]. TGF- $\beta$ signaling is an evolutionarily conserved process in which TGF- $\beta$ family cytokines induce heteromeric complexes of

\footnotetext{
*Correspondence: vdam@lumc.nl

'Ludwig Institute for Cancer Research, Uppsala University, Box 595, 75124, Uppsala, Sweden

Full list of author information is available at the end of the article
}

type I and type II serine/threonine kinase TGF- $\beta$ receptors at the cell surface, which enable the constitutively active type II receptor to phosphorylate the type I receptor. Subsequently, type I receptors activate receptorregulated Smads (R-Smads) through phosphorylation of their two carboxyl-terminal serine residues. R-Smads then can form heteromeric complexes with the commonpartner Smad (Co-Smad), Smad4, which accumulate in the nucleus and can induce cell type-specific gene expression profiles through interaction with specific subsets of other transcription factors, co-activators, and co-repressors present (Figure 1). These Smad-interacting proteins not only determine the cell type specificity and cell context specificity of the transcriptional response but also can alter the intensity and duration [2-5].

Inhibitory Smads (I-Smads) form a distinct subclass among the Smads by counteracting the signals transduced by TGF- $\beta$ receptors, R-Smads, and Co-Smads. I-Smads are part of feedback loops: they are induced by TGF- $\beta$ signaling and act by competing with R-Smads for receptor binding, thereby inhibiting $\mathrm{R}$-Smad phosphorylation [2-5] (Figure 1). The TGF- $\beta /$ Smad pathway is further controlled by multiple layers of regulation, such as signal termination by phosphatases and ubiquitin ligases. Moreover, TGF- $\beta$ can induce signaling and gene expression in a Smad-independent manner (for instance, by activating mitogen-activated protein kinases (MAPKs), PI3K-Akt/ PKB, and small GTPase pathways) [2,6] (Figure 1).

TGF- $\beta /$ Smad signaling has a biphasic role in cancer progression. In the early stages, TGF- $\beta$ can inhibit growth of epithelial cells and induce apoptosis and thus act as a tumor suppressor $[2,5]$. Escape from TGF- $\beta /$ Smadinduced growth inhibition and apoptosis is commonly observed in tumors (for instance, by inactivation mutations or deletions in core components of the pathway, such as specific receptors or Smads, or defects in the downstream targets that mediate tumor suppression $[2,5])$. Breast cancer cells frequently evade the cytostatic action of TGF- $\beta$ while retaining Smad functions. In fact, in later-stage tumors, TGF- $\beta /$ Smad signaling has been shown to promote tumor progression. Together with 


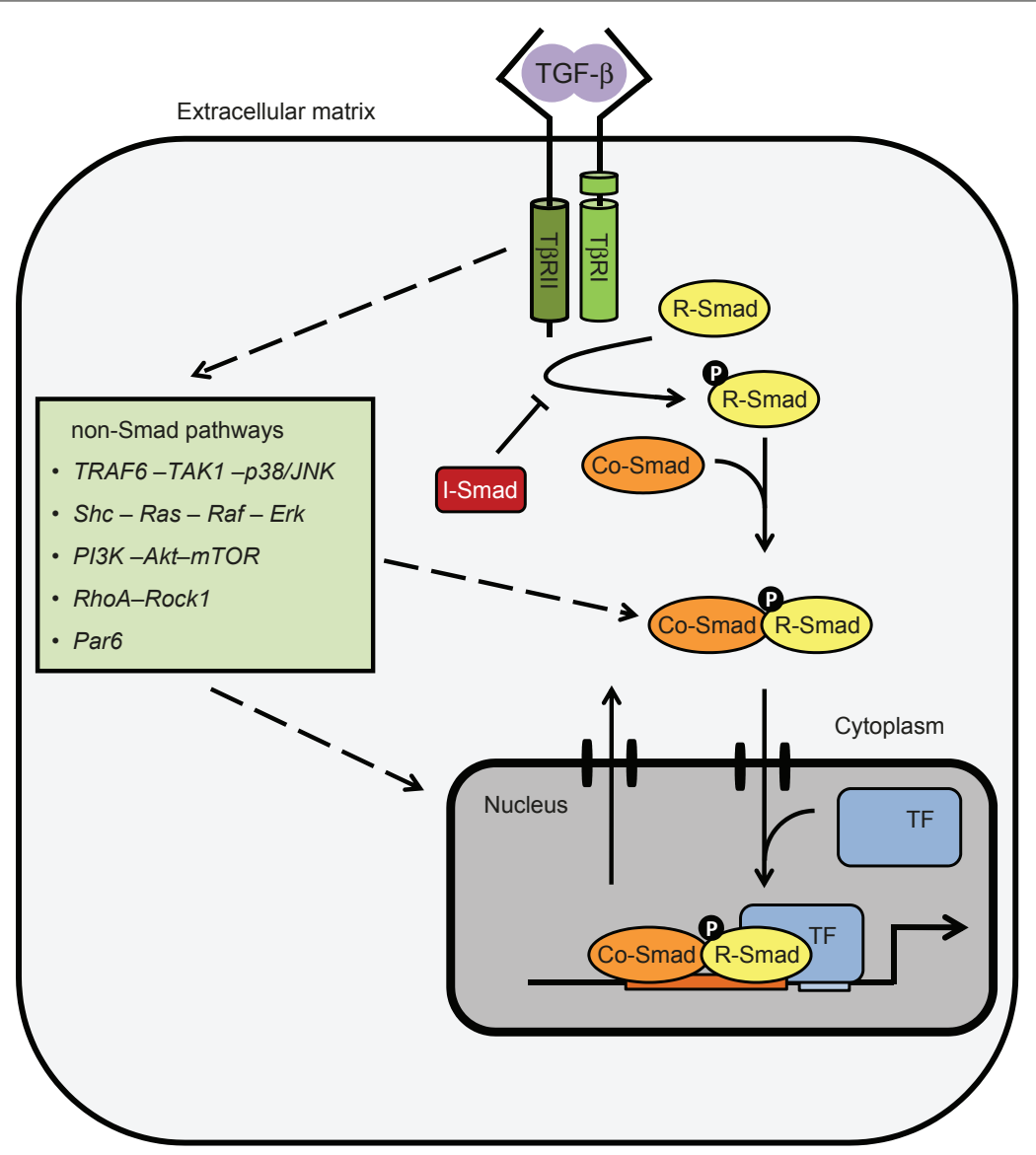

Figure 1. Smads as key mediators of transforming growth factor-beta (TGF- $\beta$ ) signaling. TGF- $\beta$ family ligands induce heteromeric complex formation of type II (TRRII) and type I (TRRI) TGF- $\beta$ receptors in the cell membrane. RII subsequently phosphorylates RI, which in turn recruits, phosphorylates, and activates R-Smads. Phosphorylated R-Smads subsequently form a complex with the co-Smad (Smad4) and then translocate into the nucleus. In the nucleus, the Smad complexes bind to other DNA-binding transcription factors, co-activators, and co-repressors to regulate the expression of a wide variety of target genes. The inhibitory Smads (Smad6/7) can reduce signaling by preventing phosphorylation of R-Smads. The strength of the signal is also regulated by the continuously shuttling of Smad complexes between the nucleus and the cytoplasm. Besides Smad-mediated signaling, TGF- $\beta$ family members can activate the indicated non-Smad pathways, several of which can influence the activity of Smad complexes and Smad target genes directly or indirectly or both. Co-Smad, common-partner Smad; I-Smad, inhibitory Smad; P, phosphate; R-Smad, receptor-regulated Smad; TF, transcription factor.

other signaling pathways activated in breast cancer, TGF- $\beta /$ Smad stimulates de-differentiation of epithelial cells to malignant invasive and metastatic fibroblastic cells $[2,5]$.

In this review, we discuss the role of Smads as signal integrators in breast epithelial plasticity and breast cancer progression, thereby describing recent studies on the molecular mechanisms, including crosstalk with other signaling pathways. In addition, we review recent work on the roles of Smads and cooperating factors in tumor invasion and metastasis.

\section{Molecular mechanisms of Smad signaling Smad domains and function}

The Smad family consists of eight members: two TGF- $\beta$ R-Smads (Smad2 and Smad3), three bone morphogenetic protein (BMP) R-Smads (Smad1, Smad5, and Smad8), one Co-Smad (Smad4), and two I-Smads (Smad6 and Smad7). At their amino-terminal and carboxyl-terminal ends, R-Smads and Co-Smads share two conserved domains - termed mad homology $(\mathrm{MH}) 1$ and $\mathrm{MH} 2$ domains, respectively - that are connected by a linker. The I-Smads have only an $\mathrm{MH} 2$ domain (Figure 2). Except for the main (long) isoform of Smad2 that contains exon 3, R-Smads and Smad4 bind DNA via the $\beta$-hairpin structure in their MH1 domains (Figure 2). Both the MH1 and $\mathrm{MH} 2$ domains mediate interactions of Smads with other transcription factors, co-activators, corepressors, and chromatin-remodeling factors. The ability of Smads to interact with other DNA-binding factors greatly facilitates gene regulation as Smads bind DNA only with rather low affinity. The MH2 domain of 


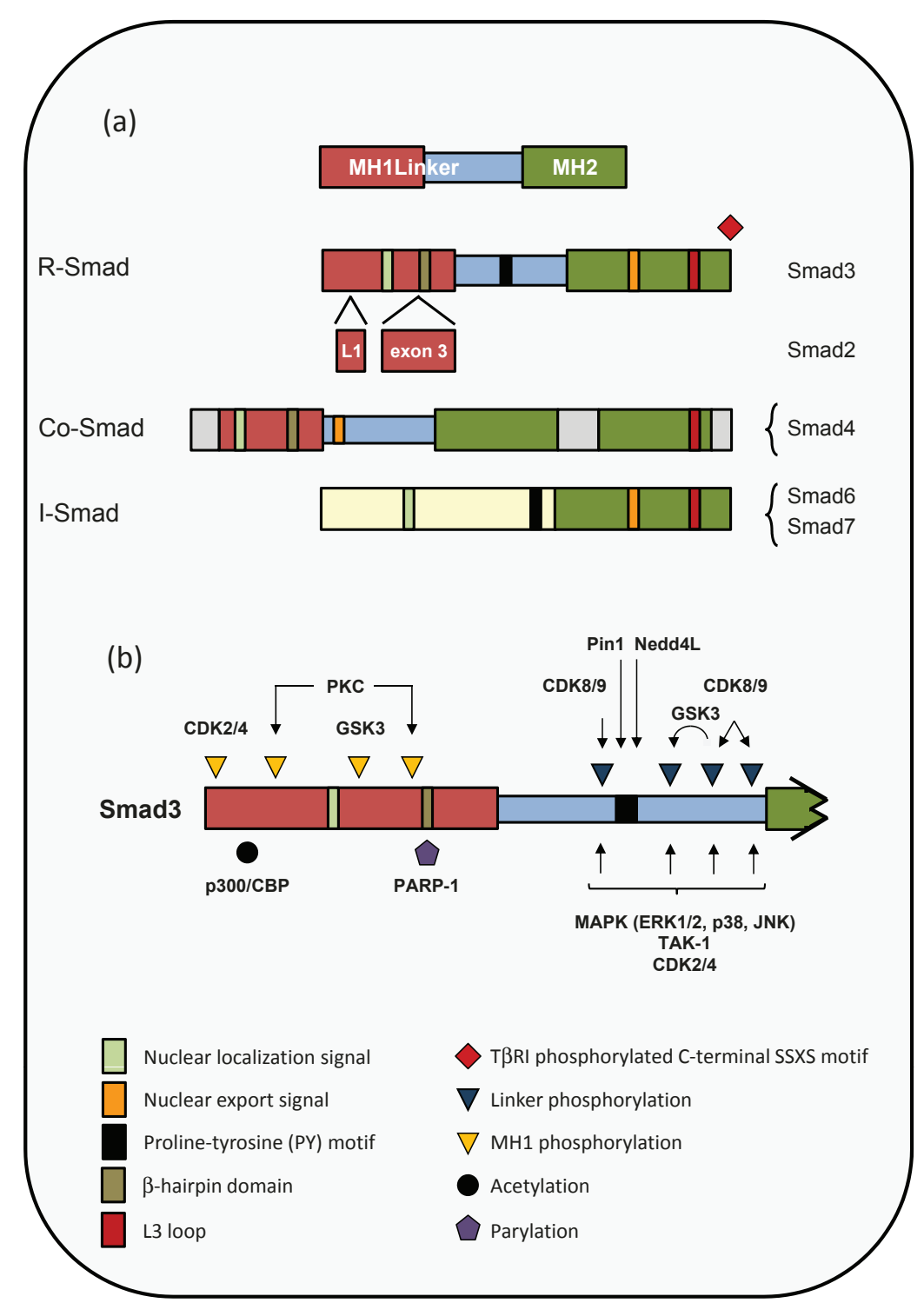

Figure 2. Schematic structure of Smad family members. (a) The schematic structure of the indicated Smads shows the homology between family members and the localization and conservation of various critical functional domains. The MH1 (red) and MH2 (green) domains are conserved among Smads, but the linker region (blue) is not conserved between the R-Smads and Smad4. The main splice variant of Smad2 contains two inserts in its $\mathrm{MH} 1$ domain (L1 and exon 3) that are not found in other R-Smads. For details on the functions of the indicated domains and motifs, see the 'Smad domains and function' and 'Regulation of Smads by phosphorylation' sections of the text. (b) A more detailed representation of the $\mathrm{MH} 1$ and linker domains of Smad3 shows various phosphorylation sites and, as examples, some of the kinases and other modifying enzymes acting on these sites and domains. Co-Smad, common-partner Smad; GSK-3, glycogen synthase kinase-3; I-Smad, inhibitory Smad; MH, mad homology; PKC, protein kinase C; R-Smad, receptor-regulated Smad.

R-Smads, in particular the L3 loop, is also responsible for the interaction of R-Smads and type I TGF- $\beta$-related receptors prior to phosphorylation, whereas the linker region between the MH1 and $\mathrm{MH} 2$ domains contains phosphorylation sites for different kinases and a polyproline-tyrosine (PY) motif that binds ubiquitin ligases (Figure 2). The roles of the various Smad domains in DNA binding and protein-protein interactions have been reviewed previously in detail [2-5].

\section{Regulation of Smads by phosphorylation}

Only the R-Smads have a conserved SSXS motif in their extreme $\mathrm{C}$-terminus that is phosphorylated by activated type I receptors (Figure 2). Whereas Smad2 and Smad3 are the major Smads downstream of TGF- $\beta$ and activin type I receptors, Smad1, Smad5, and Smad8 are phosphorylated mainly by BMP type I receptors. However, TGF- $\beta$ also can induce phosphorylation of Smad1/5 in various cell types. Phosphorylated R-Smads form 
heteromeric complexes with the Co-Smad Smad4 that then accumulate in the nucleus (Figure 1). Various studies indicate that trimeric complexes $(\mathrm{Smad} 2 / \mathrm{Smad} 2 /$ Smad4, Smad3/Smad3/Smad4, and Smad2/Smad3/ Smad 4 and mixed complexes of BMP and TGF- $\beta$ Smads) are formed, but there are also reports of dimeric complexes. Activated TGF- $\beta$ Smads bind to TGF- $\beta$-responsive elements, usually characterized by CAGA motifs, whereas activated Smad1/5-Smad4 complexes induced by BMP activate BMP-responsive elements (reviewed in [3-5]). Mixed R-Smad complexes induced by TGF- $\beta$ (containing, for instance, phosphorylated Smad1 and Smad2) do not activate BMP-responsive elements [7].

The C-terminal phosphorylation of R-Smads is counteracted by dephosphorylation by the phosphatase PPM1A and others [8,9]. Importantly, CLIC4 (chloride intracellular channel 4) and transcription factor Schnurri-2 can bind to phosphorylated Smad2 and Smad3 and thereby interfere with their dephosphorylation [10]. Phosphorylated Smad2 and Smad3 interact with importins and nucleoporins, and this promotes their nuclear translocation and also that of Smad4 [11-15]. PPM1A has been shown to facilitate the interaction of dephosphorylated Smad2/3 and nuclear export factor RanBP3 (Ranbinding protein-3), thereby coupling dephosphorylation with nuclear export to terminate TGF- $\beta /$ Smad signaling $[16,17]$. Importantly, the Hippo pathway, which senses cell density information, was recently found to determine nuclear/cytoplasmic localization of active Smad complexes via cell density-mediated formation of Crumbs polarity complexes and the transcriptional regulators TAZ and YAP [18].

Many other kinases also phosphorylate Smads. Erk1/2, p38, and JNK MAP kinases, glycogen synthase kinase-3 (GSK-3), cyclin-dependent kinases (CDK2/4/8/9), TGF- $\beta$ activated kinase-1, and $G$ protein-coupled receptor kinase-2 can all phosphorylate the Smad linker region (Figure 2), which in most cases has been found to suppress Smad activity (for instance, by enhancing degradation) [4] (see below). TGF- $\beta /$ BMP treatment thus also can induce Smad linker phosphorylation but with delayed kinetics as compared with C-terminal phosphorylation. This originally suggested that linker phosphorylation occurs as part of a negative feedback loop to remove activated Smads. However, later studies showed that linker phosphorylation also can enhance the interaction of Smads with the transcription factor YAP or Pin1 and thereby promote Smad target gene expression [19]. Differential linker serine phosphorylation by CDK8/9 and GSK-3 appears to enable R-Smads first to bind to YAP or Pin 1 and only later induces binding of the ubiquitin ligase Smurf1 or Nedd4L, which triggers R-Smad destruction (Figure 2). Smad1 phosphorylation by CDK $8 / 9$ creates binding sites for the WW domains of
YAP, but subsequent phosphorylation by GSK-3 eliminates YAP binding and creates binding sites for the WW domains of Smurf1. Similarly, Smad3 phosphorylation by CDK8/9 was found to first create binding sites for Pin1, and afterwards GSK-3 phosphorylates the sites that enhance Nedd4L binding [20]. Phosphorylation of the MH1 domain by protein kinase $\mathrm{C}$ also can inhibit Smad activity (Figure 2). In contrast, murine protein serine/ threonine kinase 38 can activate Smad functioning via phosphorylation of Smad2, Smad3, Smad4, and Smad7 [21].

Very recently, Msn members of the Ste20 family of MAP4Ks (MAP kinase kinase kinase kinases) were found to be able to block C-terminal phosphorylation of all R-Smads, except Smad3, through a single highly conserved phosphorylation event in the MH2 domain ( $\alpha$ helix 1: T322 in Smad1/5/8 and T324 in Smad2). Moreover, functional assays in cell culture and Drosophila whole animals showed that Msn kinases can suppress the biological functions of Smad [22]. In conclusion, phosphorylation of Smads can occur at multiple residues and domains and is a critical mechanism by which the TGF- $\beta$ / Smad pathway interacts with other signaling cascades, such as the Wnt/GSK-3 and Ras-MAPK pathways.

\section{Control of Smads by ubiquitination}

Ubiquitin-mediated degradation of Smads in proteasomes and lysosomes represents an important mechanism in the control of Smad stability and turnover. Various ubiquitin ligases can bind to non-activated Smads, but some appear to preferentially target activated Smad complexes and thereby trigger termination of Smad signaling. Ubiquitin ligases binding to R-Smads include the HECT ubiquitin ligases Smurf1 and Smurf2, binding to linker region PY motifs, Nedd4-2/Nedd4L, Tiul1/ WWP1, WWP2, SCF-ROC1, and CHIP $[3,4,23]$. As described above, other signaling pathways can influence R-Smad (poly-)ubiquitination and degradation via CDK8/9and GSK-3-mediated linker phosphorylation. In addition, the interaction between Smad2/3 and Smurf ubiquitin ligases can be enhanced by estrogen via Smad binding to the estrogen receptor (ER), causing estrogen-induced Smad degradation and inhibition of TGF- $\beta$ signaling [24].

Smad4 degradation can be mediated by the E3 ligases JAB1/CSN5 and SCF ${ }^{\beta T r C P}$, and mutated Smad4 found in cancers can be degraded via SCF ${ }^{\text {Skp2 }}$ [4]. Smad4 can also be mono-ubiquitinated at Lys519 by the RING-type E3

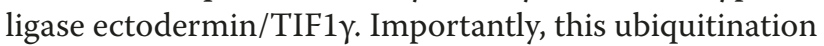
event does not affect Smad4 stability but inhibits its binding to phosphorylated Smad2. Removal of the monoubiquitin by the de-ubiquitinase FAM/USP9x restores Smad4 function [25]. Recently, both the ubiquitin ligase and transcriptional repressor activities of ectodermin/ TIF1 $\gamma$ were found to be induced by histone binding, 
suggesting that TIF1 $\gamma$ can dictate the residence time of activated Smad complexes at their target genes [26]. Intriguingly, mono-ubiquitination of Smad4 on Lys507 has been found not to inhibit but to enhance its activity [4].

Like R-Smads, inhibitory Smad7 can bind the E3 ligases Smurf1 and Smurf2 via its PY motif. This triggers recruitment of various ubiquitin ligases to the TGF- $\beta$ type I receptor and causes its subsequent degradation, which represents one of the ways by which Smad7 inhibits TGF- $\beta$ signaling. The ubiquitin ligase Arkadia controls the degradation of Smad7 itself and its binding is facilitated by axin, a scaffold protein that plays a crucial role in Wnt signaling. Interestingly, other inhibitors of Smad signaling, such as their co-repressors Ski and SnoN, can also be ubiquitinated and degraded via Arkadia [3-5]. Specific isoforms of ubiquitin ligase WWP2 also can bind and degrade Smad7 [23]. In conclusion, ubiquitin ligases and scaffold proteins not only control Smad stability and activity but also enable Smads to act as converging points between TGF- $\beta$ /BMP pathways and other signaling pathways, such as the Wnt/GSK-3 pathway.

\section{Other Smad modifications: acetylation, sumoylation, methylation, and parylation}

Acetylation of lysine residues can prevent their ubiquitination and subsequent proteasomal degradation. The coactivator and acetyl-transferase p300 can stabilize Smad7 via this mechanism, whereas various deacetylases, such as SIRT1, can render Smad7 sensitive to ubiquitination again $[4,27]$. p300/CBP-mediated acetylation of the MH1 domain of Smad2 has been reported to promote TGF- $\beta$ signaling in a ligand-dependent manner, presumably by enhancing Smad2 nuclear accumulation [28,29]. Smad3 can also be acetylated by $\mathrm{p} 300 / \mathrm{CBP}$ in the $\mathrm{MH} 2$ domain, which is associated with enhanced transcriptional activity of a GAL4-Smad3 fusion protein [30].

Sumoylation represents another post-translational modification through which Smad activity can be controlled. The E3 ligase PIAS1 can sumoylate Smad4 in its MH1 domain, which enhances TGF- $\beta$ signaling by preventing Smad4 ubiquitination and degradation. But sumoylation might also inactivate Smad4 via recruitment of transcriptional repressors (reviewed in [4]). Like acetylation, sumoylation might therefore refine the regulatory mechanisms that control Smad signaling.

Smad6 and Smad7, but not (R-)Smads and Smad4, can also be methylated by PRMT-1 (protein arginine Nmethyltransferase-1). However, the functional consequences of this modification are as yet unclear [31]. Intriguingly, PARP-1 (poly(ADP-ribose)polymerase-1) was recently reported to interact with Smad3 and Smad4 and to poly-ADP-ribosylate them. This parylation event appears to regulate the potency and duration of Smad-induced transcription by reducing Smad DNA binding [32].

\section{Control of Smad activity by protein-protein interaction}

As mentioned previously, Smad activities, in particular DNA-binding and gene activation, are also regulated extensively by protein-protein interactions. So far, Smads have been found to bind to and regulate more than 100 proteins, which include (cell type-specific) transcription factors and co-regulators, such as AP-1, Foxo, ets members, p300/CBP, and HDACs. The very large size of the Smad3 interactome supports the idea that Smads represent a critical node in the control of tissue homeostasis [33]. As protein-protein interactionmediated control by Smads has been extensively reviewed previously [2-5], we will mention only recent studies relevant for breast (cancer) development. However, it is important to stress that, via these interactions and the post-translational modifications described earlier, the TGF- $\beta$, Ras-MAPK, PI3K-Akt/PKB, Wnt/ GSK-3, and p53 pathways converge and cooperate in the nucleus through multi-protein transcriptional regulatory complexes at their target promoters (Figures 1-3). Moreover, these interactions can mechanistically explain how oncogenic mutations in these cooperating pathways can switch TGF- $\beta /$ Smad signaling from tumor suppressive to tumor promoting in cancer progression (see below).

As described in previous sections, interaction of Smads with components of other signaling pathways can also occur outside the nucleus. Relevant for the crosstalk between TGF- $\beta /$ Smad and PI3K-Akt/PKB signaling is, for instance, the direct interaction between Smad3 and Akt/PKB in the cytoplasm, preventing Smad3 phosphorylation and nuclear translocation and thereby also Smad3-mediated transcription and apoptosis [34]. Moreover, as described above, the Hippo/Taz/Yap pathway determines nuclear/cytoplasmic localization of active Smad complexes via cell density-mediated formation of Crumbs polarity complexes [18].

Also, Smad7 exhibits several functions via proteinprotein interactions. In addition to competing with R-Smads for binding to the activated type I TGF- $\beta$ receptor, Smad7 can inhibit TGF- $\beta$ signaling by recruiting phosphatases to the receptors and by inhibiting Smad binding to DNA $[3,4]$. Furthermore, Smad7 can function as an adaptor to facilitate activation of p38 MAPK [6].

Figure 3 summarizes the various ways through which Smad activity is regulated. It remains to be established to what extent phosphorylation, ubiquitination, acetylation, sumoylation, methylation, and parpylation occur simultaneously on endogenous Smad proteins in vivo, whether they are regulated by each other, and whether all of these modifications are controlled by the cellular signaling networks. Mass spectrometry approaches are expected to shed more light on this matter. 


\section{Smad Regulation}

\section{Termination / inhibitionInitiation / activation}

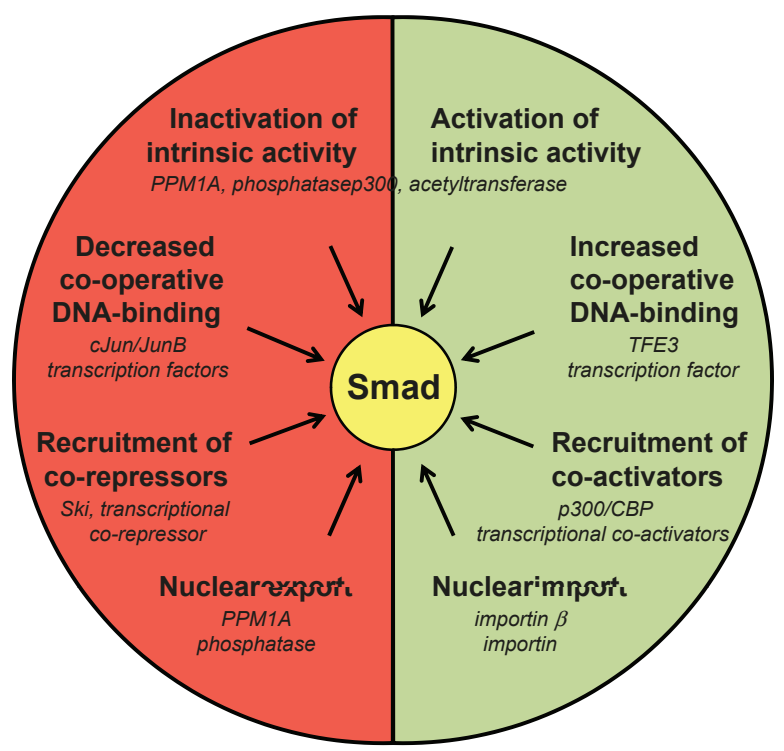

Figure 3. Schematic representation of the regulation of Smad activity in the cell. A variety of different post-translational modifications and protein-protein interactions control the properties of individual Smads or Smad complexes or both and thereby regulate their transcription factor activity and target gene specificity in a stimulus- and cell type-specific manner. For each control mechanism, one example is given [96-100].

\section{Smad-mediated functions}

Besides playing crucial roles in signal transmission and gene regulation, the Smad proteins have been found to exhibit functions such as enzyme regulation (Figure 4). The role of Smads in assembly and recruitment of ubiquitin-ligase complexes has already been described. Another activity is binding to the regulatory subunit of protein kinase A (PKA), thereby activating PKA independently of increased cAMP and mediating TGF- $\beta$ activation of CREB, induction of p21(Cip1), and inhibition of cell growth [35].

An important recently detected function of the Smads is regulation of microRNA (miRNA) processing. miRNAs are small non-coding RNAs that modulate diverse biological functions through the repression of target genes. R-Smads were found to directly interact with the RNA helicase p68, a component of the DROSHA complex that mediates the processing of miRNA precursors [36]. Smads were also shown to bind to CAGA sequences in the stem structures of a subset of miRNA precursors and thereby to facilitate their maturation [37]. It is important to note that, like Smad activity, expression of non-coding RNAs is cell type- and cell context-specific and that Smad signaling therefore results in very cell type- and cell context-specific miRNA profiles (reviewed in [5]).

\section{Mammary development, stem cells, and cancer}

TGF- $\beta$ family members, including activin, are expressed throughout mammary gland development and maintain ductal morphogenesis and architecture of the gland, regulate stem cell populations, and influence epithelial proliferation and differentiation in response to hormones. Deletion of the activin $\beta \mathrm{b}$ subunit results in incomplete mammary development and absence of lactation in mice, and TGF- $\beta$ has been shown to inhibit alveolar formation and synthesis of milk proteins and to induce apoptosis during involution of the mammary gland (reviewed in $[38,39])$. Analysis of putative mammary phenotypes in Smad knockout mice has been complicated for Smad1, Smad2, Smad4, and Smad5, which are essential for embryonic development (reviewed in [40]). Specific disruption of Smad4 in the mammary epithelium did not affect mammary gland development during the first three pregnancies but did cause a gradual enhancement of cell proliferation, alveolar hyperplasia, and transdifferentiation of mammary epithelial cells into squamous epithelial cells. As a consequence, all mutant mice developed squamous cell carcinoma or mammary abscesses or both between 5 and 16 months of age [41]. For the other Smad knockout mice, in vivo mammary phenotypes have not been reported [40,42].

\section{Normal mammary epithelial cells}

One of the functions of the TGF- $\beta /$ Smad pathway during mammary gland development is to antagonize the prolactin/JAK/STAT pathway during the control of mammary gland growth, differentiation, and lactation. For instance, activation of Smad2, Smad3, and Smad4 by activin and TGF- $\beta$ was found to block STAT5-mediated activation of $\beta$-casein and cyclin D1 expression via inhibition of the association between STAT5 and the coactivator CBP [43].

Smad2 and Smad3 appear to have specific functions in the mammary epithelium. Analysis of conditionally immortalized mammary epithelial cell lines derived from the virgin mammary glands of $H$-2Kb-tsA58 transgenic immortomice crossed with (conditional) Smad2- or Smad3-null mice showed that Smad3, but not Smad2, is critical for TGF- $\beta$-induced growth inhibition, apoptosis, and epithelial-mesenchymal transition (EMT), whereas both Smad2 and Smad3 can mediate TGF- $\beta$-induced invasion as long as a threshold level of total Smad is exceeded [44]. In a related study, RNaseH-induced mRNA degradation in NMuMG mouse mammary epithelial cells showed that Smad3, rather than Smad2, is the critical $\mathrm{R}$-Smad in TGF- $\beta$-induced target gene activation and EMT [45]. Also, in several other (breast) cancer models 


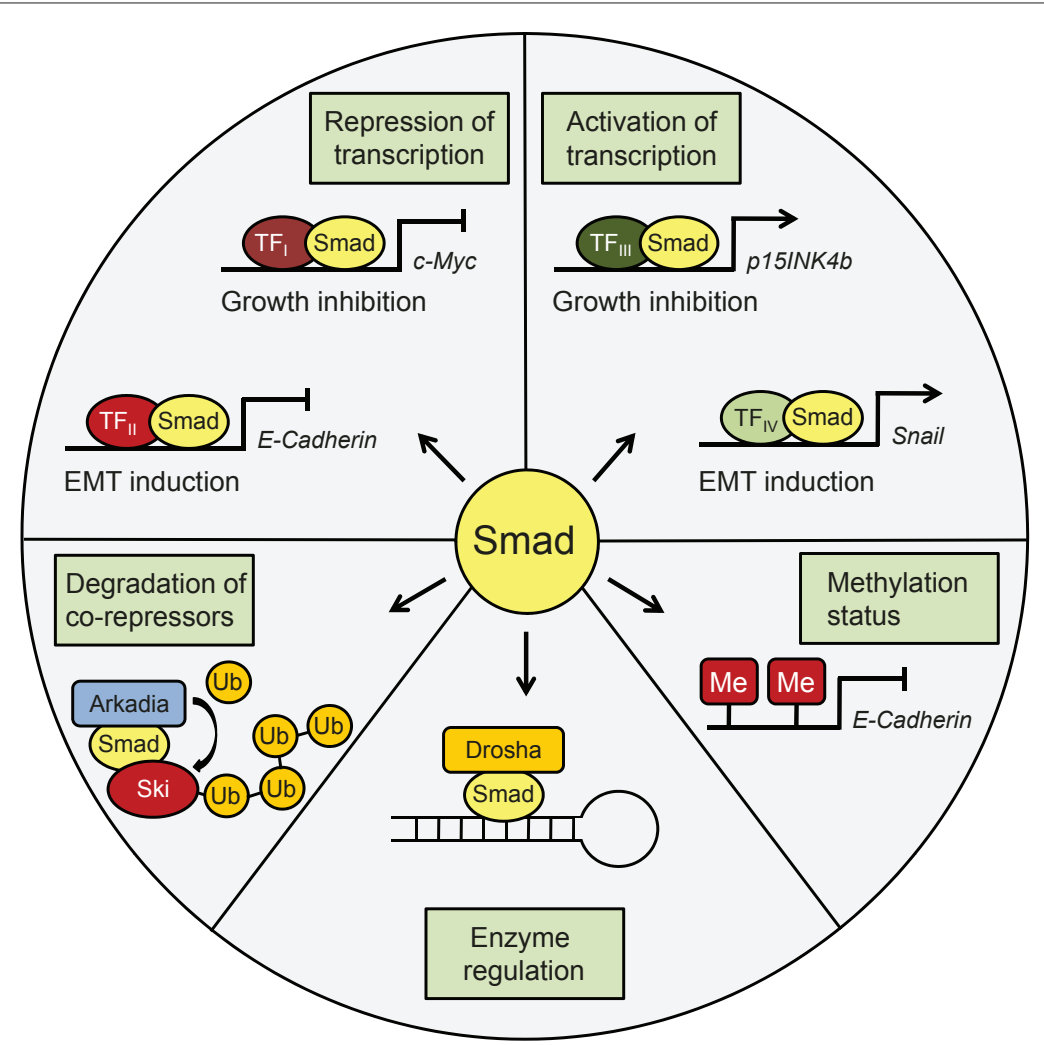

Figure 4. Schematic representation of Smad functions in the cell. The Smad complexes directly and indirectly control stimulus- and cell typespecific gene expression at multiple levels. EMT, epithelial-mesenchymal transition; Me, methyl group; TF, transcription factor; Ub, ubiquitin.

and cell types, Smad2 and Smad3 were found to exhibit distinct functions (see below).

In fact, although Smad2 and Smad3 share 92\% identity at the amino acid level, Smad2-null mice die during embryogenesis, whereas Smad3-null mice are viable and survive until adulthood. This appears to be due to differences in the Smad2 and Smad3 expression patterns rather than to different intrinsic Smad protein activities, as insertion of Smad3 into the Smad2 locus is sufficient to rescue the lethality of Smad2-null mice. However, the long Smad2 isoform that lacks intrinsic DNA-binding activity cannot rescue the Smad2-null phenotype [46]. This suggests that, when expressed at sufficient levels, the long Smad2 isoform is mainly responsible for the different behavior of Smad2 and Smad3. It is important to note that, for a given biological response, different cell types can show different Smad requirements, and this is most likely due to cell type-specific expression of the transcription factors and co-factors that cooperate with the Smads (see above).

\section{Loss of TGF- $\beta /$ Smad-dependent growth inhibition and subsequent tumor progression}

As mentioned previously, TGF- $\beta$ signaling usually acts as a tumor suppressor in the early stages of tumor development. Tumor suppressor activities of TGF- $\beta /$ Smad signaling include repression of c-myc [47] and induction of cyclin-dependent kinase inhibitors (reviewed in $[2,5,48]$ ). During cancer progression, accumulation of genetic mutations as well as epigenetic changes can render cells insensitive to the cytostatic effects of TGF- $\beta$, and core components of the TGF- $\beta$ pathway, including Smad2, Smad3, and Smad4, are frequently inactivated in a subset of cancer specimens (for instance, in colorectal cancer) [4951]. However, breast cancers often carry defects only in downstream mediators of the cytostatic action of TGF- $\beta$, show normal TGF- $\beta$ signaling from receptors to Smads, and retain or gain other TGF- $\beta$-responsive properties, indicating that TGF- $\beta /$ Smad signaling is critical for breast cancer progression [48,51-55]. A large number of studies support the positive role of TGF- $\beta /$ Smads in late breast cancer. For instance, transgenic mice expressing an activated TGF- $\beta$ type I receptor or dominant negative TGF- $\beta$ type II receptor under control of the mouse mammary tumor virus promoter showed that TGF- $\beta$ impairs mammary tumorigenesis induced by activated forms of the Neu receptor tyrosine kinase but promotes the formation of lung metastases [56]. Moreover, reduction in Smad2/3 signaling was found to enhance tumorigenesis but to suppress metastasis of breast cancer cell lines [57]. 
One of the important issues in breast cancer research is what switches TGF- $\beta$ and Smads from tumor suppressors to tumor promoters during the later stages of cancer progression $[2,58]$. As mentioned previously, oncogenic mutations in Ras-MAPK, PI3K-Akt/PKB, Wnt, p53, Myc, and other TGF- $\beta /$ Smad-interacting pathways can make cells insensitive to TGF- $\beta$-induced growth arrest and apoptosis. However, these oncogenic events can also specifically enhance pro-invasive and pro-metastatic TGF- $\beta$ responses in epithelial cells, and this often involves a change in the balance between canonical Smad and non-Smad signaling [2,5,48,59-61]. For instance, TGF- $\beta$, oncogenic Ras, and mutant-p53 together can induce the formation of a Smad/mutant-p53/p63 ternary protein complex in which the suppressive function of p63 is inhibited, resulting in activation of genes that promote migration, invasion, and metastasis [62]. Moreover, transformation by oncogenic Ras was found to strongly enhance the Smad-dependent invasion of breast cancer cells in a collagen matrix [59,63]. Radiation carcinogenesis studies that include stromal or epithelial TGF- $\beta$ depletion suggest that the TGF- $\beta$ switch from tumor suppressor to tumor promoter involves distinct stromal versus epithelial actions, in particular pro-tumorigenic stromal remodeling [64].

As described in the following sections, many preclinical studies indicate that TGF- $\beta$ and Smads can promote tumor invasion and metastasis through EMT, through enhanced motility, invasion, and survival of the tumor cell, and by affecting the tumor stroma via the extracellular matrix composition. TGF- $\beta$ and Smads can also stimulate angiogenesis and suppress immunosurveillance (reviewed in $[2,39,65]$ ). Moreover, EMT has been found to produce cancer cells that express stem cell markers and exhibit stem cell characteristics, suggesting that cancer cells that undergo EMT can metastasize through acquired invasiveness and, upon dissemination, through enhanced self-renewal potential, enabling them to grow out into macroscopic metastases [66].

\section{Epithelial-to-mesenchymal transition}

As mentioned earlier, TGF- $\beta /$ Smad signaling can stimulate de-differentiation of epithelial cells to malignant invasive and metastatic mesenchymal cells. In general, EMT is characterized by disassembly of adherence junctions, tight junctions, desmosomes, or gap junctions and by activation of the cytoskeletal and signaling systems involved in migration and invasion. Moreover, changes in expression of specific membrane proteins and secreted cytokines, such as downregulation of E-cadherin and upregulation of $\mathrm{N}$-cadherin, can occur.

EMT is also promoted by several other developmental and morphogenetic signaling pathways, such as the Wnt, Notch, and hedgehog (stem cell) pathways, and pathways controlled by receptor tyrosine kinases and hormonedependent nuclear receptors, such as the Ras-MAPK pathway $[67,68]$. These EMT pathways already function during embryogenesis and can be reactivated abnormally during cancer progression. As mentioned above, cooperation and convergence of these pathways can occur in multi-protein transcriptional regulatory complexes in the nucleus, such as so-called EMT-promoting Smad complexes (EPSCs) - containing EMT-associated transcription factors such as Snail1, Zeb1/2, Twist, $\beta$-catenin, Lef/TCF, Foxc2, and AP-1 - that repress epithelial genes and activate mesenchymal genes [68] (Figure 4). The interplay between Smads and Snail1 represents a good example of the complexity of EMT induction by the TGF- $\beta$ /Smad pathway. Smad2, Smad3, and Smad4 directly bind to the Snail1 promoter and induce its expression in cooperation with the architectural nuclear factor HMGA2 (high-mobility group 2) [4]. However, after induction, the Smads also bind to the Snail1 protein and, together with Snail1, repress a large group of epithelial genes, including E-cadherin and occludin [68].

Interestingly, stable transformation of EpH4 normal mouse mammary gland epithelial cells by oncogenic $\mathrm{H}$-Ras was found to result in strong reduction of the Smad3 levels and to render these cells insensitive to TGF- $\beta$-induced growth inhibition but susceptible for EMT and invasive growth. Ectopic expression of Smad3 in EpRas cells restored growth inhibition by TGF- $\beta$ but did not affect EMT induction [69]. Since Smad3 levels are often reduced in advanced human tumors $([69,70]$ and references therein), these results suggest that the expression level of Smad3 might be an important determinant of tumor progression, high levels being required for tumor suppression by TGF- $\beta$ and low levels being sufficient for tumor promotion [69].

In addition to the pathways mentioned above, the translation activating mammalian target of rapamycin (mTOR) pathway can complement the TGF- $\beta /$ Smad pathway in inducing EMT in mouse epithelial cells. TGF- $\beta$ was found to activate mTOR through PI3K and $\mathrm{AKT} / \mathrm{PKB}$, leading to the phosphorylation of S6 kinase 1 and eukaryotic initiation factor 4E-binding protein 1 , direct regulators of translation initiation [6,71].

The pro-oncogenic functions of Smads in mammary epithelial cells also are exhibited via crosstalk with the p53, Myc, and IKK-NF-кB pathways [4,62,72,73] (see above). For instance, TGF- $\beta 1$-activated Smad3 and Smad4 were found to bind specifically to the second promoter region of the p53 E3 ligase human murine double minute (HDM2), causing increased HDM2 protein expression and destabilization of p53 in human cancer cell lines. During EMT in murine mammary epithelial cells, TGF- $\beta 1$ expression also induced Mdm2 (murine double 
minute 2) expression, which may represent a critical prosurvival mechanism in cancer progression [72].

The ability of Smad proteins to regulate miRNA processing is of particular interest in EMT because miR-200 family miRNAs have been found to be downregulated by TGF- $\beta$ /Smad signaling. miR-200 downregulation results in the upregulation of several EMT-regulating genes, notably Zeb1/2 and TGF- $\beta 2$, and thus represents a positive feed-forward loop [5,74]. Moreover, Smads induce the miR-155 gene, which regulates actin dynamics and inhibits epithelial polarity via its effects on the small GTPase RhoA [75]. In addition, TGF- $\beta$ has been found to regulate the sphere-initiating stem cell-like feature in breast cancer through miRNA-181 and ATM [76].

Another important EMT-related function of Smads in breast cancer is maintenance of epigenetic silencing. Disruption of TGF- $\beta /$ Smad2 signaling by Smad7 overexpression or Smad2 knockdown in the spindle-shaped mesenchymal-like MCF10A-MIII cells was found to interfere with DNA hypermethylation and silencing of epithelial genes (Figure 4). This silencing might be mediated by Smad2-dependent activation of the DNA methyl-transferase DNMT1 [77].

\section{Tumor-stroma interactions and invasion}

In vivo, tumor cells interact both with extracellular matrix components such as laminin, fibronectin, and collagen and with cells in the tumor stroma. Likewise, various types of non-tumor cells such as fibroblasts, macrophages, and other immune cells are affected by, and attracted to, the tumor cells via secreted growth factors and cytokines. TGF- $\beta /$ Smad signaling thus can mediate its functions in cancer both through autonomous tumor cell signaling and via interactions with the tumor microenvironment, in particular at the tumor-invasion front, where the levels of TGF- $\beta$ are high. Moreover, TGF- $\beta /$ Smad signaling in stromal fibroblasts and mesenchymal stem cells might contribute to their ability to promote breast cancer metastasis $[2,78,79]$.

As mentioned above, TGF- $\beta /$ Smad signaling can enhance cancer progression when the tumor cells have become insensitive to its growth-suppressive effects. TMEPAI, a TGF- $\beta$-induced transmembrane protein that can bind to NEDD4 E3 ubiquitin ligase and that is overexpressed in several cancers, appears to play an important role in this since it seems to convert TGF- $\beta$ from a tumor suppressor to a tumor promoter. TMEPAI enhanced TGF- $\beta$-induced growth, motility, and invasion in breast cancer cells but decreased breast tumor mass in a mouse xenograft model. This decrease was associated with increased expression of PTEN (phosphatase and tensin homologue), an inhibitor of the PI3K-Akt/PKB pathway [80]. In addition, TMEPAI can sequester Smad proteins to decrease TGF- $\beta$ signaling as part of a negative feedback loop, which diminishes the TGF- $\beta /$ Smadinduced growth-inhibitory effects [81].

Similar to the TGF- $\beta /$ Smad pathway, the BMP/Smad signaling pathway appears to posses both tumor-suppressive and oncogenic properties in breast cancer (reviewed in [82]). For instance, BMP7 can counteract (part of) the EMT program, can both positively and negatively affect proliferation of breast cancer cells depending on the cell line, and can increase migration and invasion of some types of breast cancer cells. BMP7 expression was also found to be inversely related to tumorigenicity and invasive behavior of human breast cancer cells, and exogenous addition of BMP7 inhibited Smad-mediated TGF- $\beta$ signaling in the metastatic MDA-231 breast cancer cells [83].

BMP7 also can inhibit TGF- $\beta$-induced collagen invasion of breast cancer cells, but this does not seem to involve direct effects of BMP7 on TGF- $\beta$-induced Smads [84]. In a spheroid invasion model, Smad3 and Smad4 are critical for TGF- $\beta$-induced invasion of oncogenically transformed human MCF10A cells. Matrix metalloproteinases 2 and 9 were found to be critical Smaddependent invasion genes in this system, but other TGF- $\beta$ target genes play a role as well [63]. Intriguingly, only some of these Smad-dependent invasion genes were inhibited by BMP7 and not by the highly related BMP6 [84]. Another BMP, BMP4, was found to cause $G_{1}$ cell cycle arrest in several breast cancer cell lines but stimulated migration and invasion in only a subset of these lines [85].

The role of BMP-induced Smad1/5/8 in these processes remains to be established. Interestingly, non-canonical TGF- $\beta$-induced Smad1/5 phosphorylation (see above) is not required for TGF- $\beta$-induced growth arrest or EMT but appears to mediate TGF- $\beta$-induced anchorage-independent growth in (Ras-transformed) mouse mammary epithelial cells [7] and also seems to initiate and promote TGF- $\beta$ stimulated migration [86].

TGF- $\beta$ was also found to switch breast cancer cells from cohesive to single-cell motility through a transcriptional program involving Smad4, EGFR, Nedd9, M-RIP, FARP, and RhoC. Inhibition of TGF- $\beta$ signaling in vivo prevented cells from moving singly but did not inhibit cells from moving collectively, and cells restricted to collective invasion were capable of lymphatic invasion but not blood-borne metastasis [87].

ER-mediated Smad degradation via Smurfs (see above), resulting in inhibition of TGF- $\beta$-induced migration, invasion, and (possibly) EMT, might represent one of the mechanisms by which ER signaling and TGF- $\beta$ signaling cross-talk in breast cancer [24] (reviewed in [88]). Although breast cancer is typically hormone-dependent and estrogen can enhance cellular growth and proliferation of breast cancer cells, estrogen might suppress 


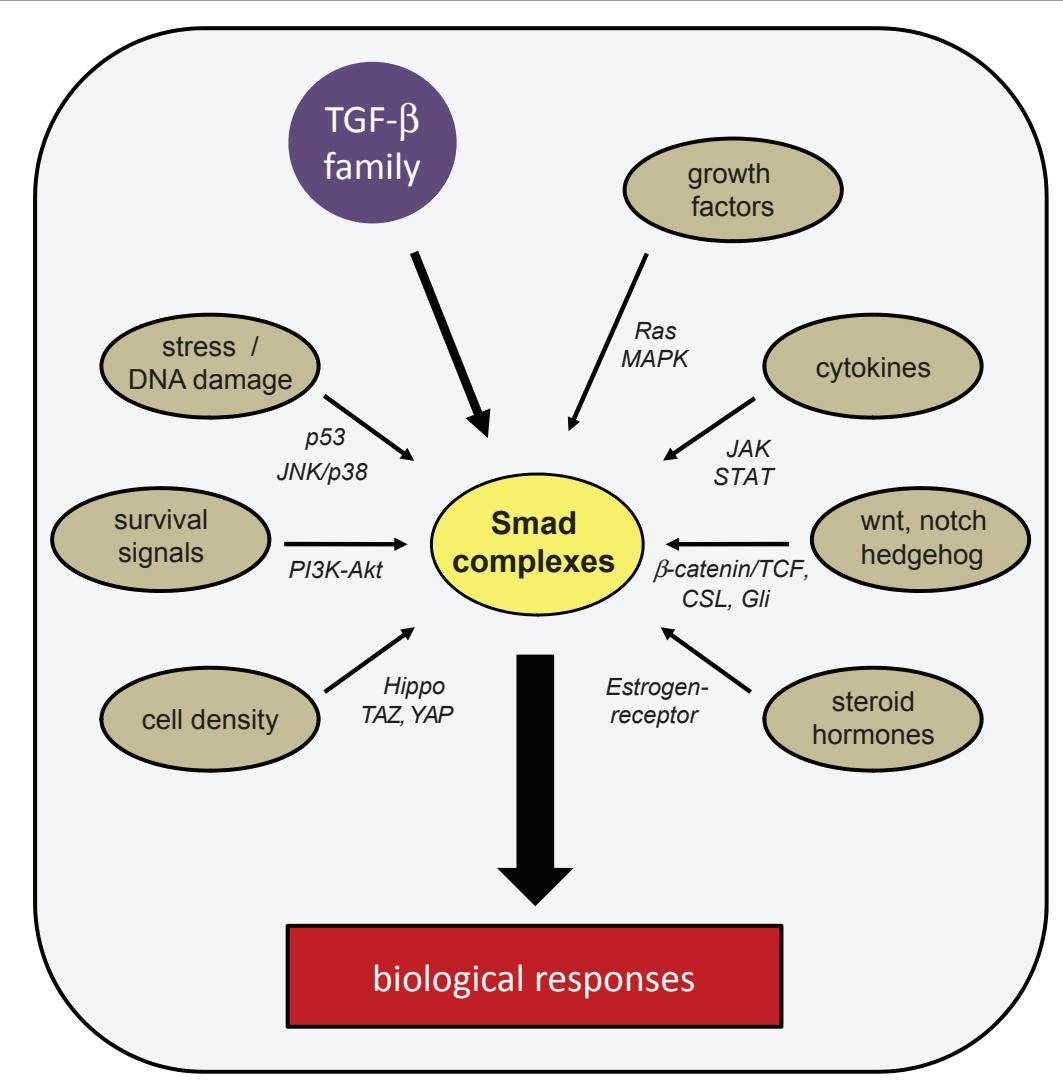

Figure 5. Schematic representation of signal integration by Smad complexes. Multiple types of signaling pathways converge at the level of Smad complexes to regulate cellular behavior in a stimulus- and microenvironment-specific manner. Various cytokines signal through JAK (Janus kinase) and STAT (signal transducer and activator of transcription). The developmental stimuli wnt, notch, and hedgehog signal and activate transcription via $\beta$-catenin/TCF, CSL, and Gli, respectively. CSL (C-promoter-binding factor 1 (CBF-1), suppressor of hairless (Su(H)), lin-12 and glp-1 (Lag-1)); TCF, T-cell factor; TGF- $\beta$, transforming growth factor-beta.

invasion and metastasis in the later stages of breast cancer. In fact, ER-negative breast tumors are less differentiated and more difficult to cure [88]. However, it remains to be established whether Smad levels are decreased in ER-positive tumors. In this respect, it should be mentioned that amplification of HER- 2 can potentiate TGF- $\beta$-induced invasion (see below).

\section{Metastasis}

The Smad proteins also exhibit critical function in metastasis formation. As discussed above, Smads can cooperate with oncogenic Ras and the p53 family tumor suppressor pathway in breast cancer progression, which results in activation of genes that promote migration, invasion, and metastasis [62]. Knockdown studies showed that Smad4 is required for bone metastasis of breast cancer cells but mainly for the initial establishment and less for metastasis maintenance or progression of already-established macrometastases $[89,90]$. Owing to their different effects on tumor angiogenesis, Smad2 and Smad3 have opposing roles in breast cancer bone metastasis [91]. In line with the positive role of Smad4 and Smad3 in bone metastasis, RNAi (RNA interference)mediated knockdown of the Smad co-repressor c-Ski enhanced tumor metastasis in vivo but did not affect tumor growth. Moreover, TGF- $\beta$ was found to trigger degradation of Ski via the E3 ligase Arkadia, and this required binding of phosphorylated Smad2 or Smad3 [92].

The HER-2 receptor tyrosine kinase - amplified in approximately $25 \%$ of invasive human breast cancers also can affect TGF- $\beta /$ Smad signaling. HER-2 overexpression differentially alters TGF- $\beta$ responses in luminal versus mesenchymal human breast cancer cells and potentiates the TGF- $\beta$-induced pro-invasive and pro-metastatic gene signature in the mesenchymal breast cell line MDA-MB-231 [93]. In contrast, HER-2 silences TGF- $\beta$ - and oncogene-induced sencescence-mediated tumor suppression by switching expression of transcription factor C/EBP $\beta$ isoforms. This HER-2-induced isoform switching prevents the assembly of C/EBP/Smad transcriptional repressor complexes [94]. Another 
modulator of TGF- $\beta /$ Smad signaling involved in metastasis is the calcium/phospholipid-binding and actin regulatory protein Annexin A1. This protein was found to promote lung metastasis formation of basal-like breast cancer cells by enhancing TGF- $\beta /$ Smad signaling and actin reorganization, thereby allowing efficient cell migration and invasion of metastatic breast cancer cells [95].

Finally, as mentioned above, BMP7 can inhibit Smadmediated TGF- $\beta$ signaling in metastatic MDA-231 cells. Importantly, BMP7 also inhibited de novo formation and progression of osteolytic bone metastases of these cells [83]. However, it should be noted that BMPs can also have positive effects on breast cancer metastasis (reviewed in [82]).

\section{Conclusions and perspectives}

R-Smads, Co-Smads, and I-Smads transmit and integrate a large amount of distinct and context-specific positive and negative growth signals elicited by TGF- $\beta$ superfamily ligands and other signaling networks. The Smads perform these functions in a cell- and microenvironmentspecific manner through a large number of distinct protein-protein interactions and post-translational modifications and also via regulation of miRNA processing. By regulating genes controlling cell cycle arrest, apoptosis, EMT, migration, invasion, and metastasis formation, Smads have crucial functions in both breast development and breast cancer. Crosstalk, both direct and indirect (via target genes), with the Ras-MAPK, PI3K-Akt/PKB, and p53 pathways (among others) determines the actual biological outcome of Smad signaling (Figure 5). Future work is likely to reveal new insights in the functions of Smads in (cancer) stem cells, cancer-associated fibroblasts, and mesenchymal stem cells, in particular with respect to invasion and metastasis. In addition, the therapeutic potential of specific inhibitors of the TGF- $\beta$ / Smad pathway is heavily investigated at present.

This article is part of a review series on Key signalling nodes in mammary gland development and cancer, edited by Adrian Lee and Charles Streuli. Other articles in the series can be found online at http://breast-cancer-research.com/series/signalling_nodes.

\section{Abbreviations}

BMP, bone morphogenetic protein; CDK, cyclin-dependent kinase; Co-Smad, common-partner Smad; EMT, epithelial-mesenchymal transition; ER, estrogen receptor; GSK-3, glycogen synthase kinase-3; HDM2, human murine double minute; I-Smad, inhibitory Smad; MAPK, mitogen-activated protein kinase; $\mathrm{MH}$, mad homology; miRNA, microRNA; mTOR, mammalian target of rapamycin; PKA, protein kinase A; PY, polyproline-tyrosine; R-Smad, receptorregulated Smad; STAT, signal transducer and activator of transcription; TGF- $\beta$, transforming growth factor-beta.

\section{Competing interests}

The authors declare that they have no competing interests.

\section{Acknowledgments}

We thank our colleagues, in particular, Long Zhang, for valuable discussion and apologize to all of our colleagues whose work we could not cite directly, because of a limited amount of space. Our studies on Smads in breast cancer are supported by Swedish Cancerfonden (09 0773) and the Netherlands Centre for Biomedical Genetics.

\section{Author details}

'Ludwig Institute for Cancer Research, Uppsala University, Box 595, 75124, Uppsala, Sweden. ${ }^{2}$ Department of Molecular Cell Biology and Centre for Biomedical Genetics, Leiden University Medical Center, P.O. box 9600, 2300 RC, Leiden, The Netherlands.

Published: 8 February 2012

\section{References}

1. Derynck R, Gelbart WM, Harland RM, Heldin CH, Kern SE, Massagué J, Melton DA, Mlodzik M, Padgett RW, Roberts AB, Smith J, Thomsen GH, Vogelstein B, Wang XF: Nomenclature: vertebrate mediators of TGFbeta family signals. Cell 1996, 87:173

2. Massagué J: TGFbeta in cancer. Cell 2008, 134:215-230.

3. Ross S, Hill CS: How the Smads regulate transcription. Int J Biochem Cell Biol 2008, 40:383-408.

4. Heldin $\mathrm{CH}$, Moustakas A: Role of Smads in TGF $\beta$ signaling: Cell Tissue Res 2011 Jun 4. [Epub ahead of print].

5. Ikushima H, Miyazono K: TGF- $\beta$ signal transduction spreading to a wider field: a broad variety of mechanisms for context-dependent effects of TGF- $\beta$. Cell Tissue Res 2011 May 27. [Epub ahead of print].

6. Mu Y, Gudey SK, Landström M: Non-Smad signaling pathways. Cell Tissue Res 2011 Jun 24. [Epub ahead of print]

7. Daly AC, Randall RA, Hill CS: Transforming growth factor beta-induced Smad $1 / 5$ phosphorylation in epithelial cells is mediated by novel receptor complexes and is essential for anchorage-independent growth. Mol Cell Biol 2008, 28:6889-6902.

8. Lin $X$, Duan $X$, Liang YY, Su Y, Wrighton $\mathrm{KH}$, Long J, Hu M, Davis CM, Wang J, Brunicardi FC, Shi Y, Chen YG, Meng A, Feng XH: PPM1A functions as a Smad phosphatase to terminate TGFbeta signaling. Cell 2006, 125:915-928.

9. Liu T, Feng XH: Regulation of TGF-beta signalling by protein phosphatases. Biochem J 2010, 430:191-198.

10. Shukla A, Malik M, Cataisson C, Ho Y, Friesen T, Suh KS, Yuspa SH: TGF- $\beta$ signalling is regulated by Schnurri-2-dependent nuclear translocation of CLIC4 and consequent stabilization of phospho-Smad2 and 3. Nat Cell Biol 2009, 11:777-784.

11. Xiao Z, Liu X, Lodish HF: Importin $\beta$ mediates nuclear translocation of Smad 3. J Biol Chem 2000, 275:23425-23428.

12. Kurisaki A, Kose S, Yoneda Y, Heldin C-H, Moustakas A: Transforming growth factor- $\beta$ induces nuclear import of Smad3 in an importin- $\beta 1$ and Randependent manner. Mol Biol Cell 2001, 12:1079-1091.

13. Xu L, Kang Y, Col S, Massagué J: Smad2 nucleocytoplasmic shuttling by nucleoporins CAN/Nup214 and Nup153 feeds TGF $\beta$ signaling complexes in the cytoplasm and nucleus. Mol Cell 2002, 10:271-282.

14. Xu L, Yao X, Chen X, Lu P, Zhang B, Ip YT: Msk is required for nuclear import of TGF- $\beta$ /BMP-activated Smads. J Cell Biol 2007, 178:981-994.

15. Yao X, Chen X, Cottonham C, Xu L: Preferential utilization of $I m p 7 / 8$ in nuclear import of Smads. J Biol Chem 2008, 283:22867-22874.

16. Kurisaki A, Kurisaki K, Kowanetz M, Sugino H, Yoneda Y, Heldin C-H, Moustakas A: The mechanism of nuclear export of Smad3 involves exportin 4 and Ran. Mol Cell Biol 2006, 26:1318-1332.

17. Dai F, Lin X, Chang C, Feng XH. Nuclear export of Smad2 and Smad3 by RanBP3 facilitates termination of TGF-beta signaling. Dev Cell 2009, 16:345-357.

18. Varelas X, Samavarchi-Tehrani P, Narimatsu M, Weiss A, Cockburn K, Larsen BG, Rossant J, Wrana JL: The Crumbs complex couples cell density sensing to Hippo-dependent control of the TGF- $\beta$-SMAD pathway. Dev Cell 2010, 19:831-844.

19. Alarcón C, Zaromytidou Al, Xi Q, Gao S, Yu J, Fujisawa S, Barlas A, Miller AN, Manova-Todorova K, Macias MJ, Sapkota G, Pan D, Massagué J: Nuclear CDKs drive Smad transcriptional activation and turnover in BMP and TGF- $\beta$ pathways. Cell 2009, 139:757-769.

20. Aragón E, Goerner N, Zaromytidou Al, Xi Q, Escobedo A, Massagué J, Macias MJ: A Smad action turnover switch operated by WW domain readers of a 
phosphoserine code. Genes Dev 2011, 25:1275-1288.

21. Seong $H-A$, Jung $H$, Ha H: Murine protein serine/threonine kinase 38 stimulates TGF- $\beta$ signaling in a kinase-dependent manner via direct phosphorylation of Smad proteins. J Biol Chem 2010, 285:30959-30970.

22. Kaneko S, Chen X, Lu P, Yao X, Wright TG, Rajurkar M, Kariya KI, Mao J, Ip YT, Xu L: Smad inhibition by the Ste20 kinase Misshapen. Proc Natl Acad Sci U S A 2011 Jun 20. [Epub ahead of print].

23. Soond SM, Chantry A: Selective targeting of activating and inhibitory Smads by distinct WWP2 ubiquitin ligase isoforms differentially modulates TGF $\beta$ signalling and EMT. Oncogene 2011, 30:2451-2462.

24. Ito I, Hanyu A, Wayama M, Goto N, Katsuno Y, Kawasaki S, Nakajima Y, Kajiro M, Komatsu Y, Fujimura A, Hirota R, Murayama A, Kimura K, Imamura T, Yanagisawa J: Estrogen inhibits transforming growth factor beta signaling by promoting Smad2/3 degradation. J Biol Chem 2010, 285:14747-14755.

25. Dupont S, Mamidi A, Cordenonsi M, Montagner M, Zacchigna L, Adorno M, Martello G, Stinchfield MJ, Soligo S, Morsut L, Inui M, Moro S, Modena N, Argenton F, Newfield SJ, Piccolo S: FAM/USP9x, a deubiquitinating enzyme essential for TGF $\beta$ signaling, controls Smad4 monoubiquitination. Cell 2009, 136:123-135

26. Agricola E, Randall RA, Gaarenstroom T, Dupont S, Hill CS: Recruitment of TIF1 $y$ to chromatin via its PHD finger-bromodomain activates its ubiquitin ligase and transcriptional repressor activities. Mol Cell 2011, 43:85-96.

27. Kume S, Haneda M, Kanasaki K, Sugimoto T, Araki S, Isshiki K, Isono M, Uzu T, Guarente L, Kashiwagi A, Koya D: SIRT1 inhibits transforming growth factor beta-induced apoptosis in glomerular mesangial cells via Smad7 deacetylation. J Biol Chem 2007, 282:151-158.

28. Simonsson M, Kanduri M, Grönroos E, Heldin CH, Ericsson J: The DNA binding activities of $S \mathrm{mad} 2$ and $\mathrm{Smad} 3$ are regulated by coactivatormediated acetylation. J Biol Chem 2006, 281:39870-39880

29. Tu AW, Luo K: Acetylation of Smad2 by the co-activator p300 regulates activin and transforming growth factor beta response. J Bio/ Chem 2007, 282:21187-21196

30. Inoue Y, Itoh Y, Abe K, Okamoto T, Daitoku H, Fukamizu A, Onozaki K, Hayashi $\mathrm{H}: \mathrm{Smad} 3$ is acetylated by $\mathrm{p} 300 / \mathrm{CBP}$ to regulate its transactivation activity. Oncogene 2007, 26:500-508.

31. Inamitsu M, Itoh S, Hellman U, Ten Dijke P, Kato M: Methylation of Smad6 by protein arginine N-methyltransferase 1. FEBS Lett 2006, 580:6603-6611.

32. Lönn P, van der Heide LP, Dahl M, Hellman U, Heldin CH, Moustakas A: PARP-1 attenuates Smad-mediated transcription. Mol Cell 2010, 40:521-532.

33. Taylor IW, Wrana JL: SnapShot: The TGFbeta pathway interactome. Cell 2008, 133:378.

34. Conery AR, Cao Y, Thompson EA, Townsend CM Jr., Ko TC, Luo K: Akt interacts directly with Smad3 to regulate the sensitivity to TGF-beta induced apoptosis. Nat Cell Biol 2004, 6:366-372.

35. Zhang L, Duan CJ, Binkley C, Li G, Uhler MD, Logsdon CD, Simeone DM. A transforming growth factor beta-induced $\mathrm{Smad} 3 / \mathrm{Smad} 4$ complex directly activates protein kinase A. Mol Cell Biol 2004, 24:2169-2180.

36. Davis BN, Hilyard AC, Lagna G, Hata A: SMAD proteins control DROSHAmediated microRNA maturation. Nature 2008, 454:56-61.

37. Davis BN, Hilyard AC, Nguyen PH, Lagna G, Hata A: Smad proteins bind a conserved RNA sequence to promote microRNA maturation by Drosha. Mol Cell 2010, 39:373-384.

38. Flanders KC, Wakefield LM: Transforming growth factor-( $(\beta)$ s and mammary gland involution; functional roles and implications for cancer progression. J Mammary Gland Biol Neoplasia 2009, 14:131-144

39. Tan $A R$, Alexe $G$, Reiss $M$ : Transforming growth factor- $\beta$ signaling: emerging stem cell target in metastatic breast cancer? Breast Cancer Res Treat 2008, 115:453-495.

40. Chang H, Brown CW, Matzuk MM: Genetic analysis of the mammalian transforming growth factor-beta superfamily. Endocr Rev 2002, 23:787-823.

41. Li W, Qiao W, Chen L, XU X, Yang X, Li D, Li C, Brodie SG, Meguid MM, Hennighausen L, Deng CX: Squamous cell carcinoma and mammary abscess formation through squamous metaplasia in Smad4/Dpc4 conditional knockout mice. Development 2003, 130:6143-6153.

42. Chen Q, Chen H, Zheng D, Kuang C, Fang H, Zou B, Zhu W, Bu G, Jin T, Wang Z, Zhang X, Chen J, Field LJ, Rubart M, Shou W, Chen Y: Smad7 is required for the development and function of the heart. J Biol Chem 2009, 284:292-300,

43. Cocolakis E, Dai M, Drevet L, Ho J, Haines E, Ali S, Lebrun JJ: Smad signaling antagonizes STAT5-mediated gene transcription and mammary epithelial cell differentiation J Biol Chem 2008, 283:1293-1307.

44. Kohn EA, Du Z, Sato M, Van Schyndle CM, Welsh MA, Yang YA, Stuelten $C H$,
Tang B, Ju W, Bottinger EP, Wakefield LM: A novel approach for the generation of genetically modified mammary epithelial cell cultures yields new insights into TGF $\beta$ signaling in the mammary gland. Breast Cancer Res 2010, 12:R83.

45. Dzwonek J, Preobrazhenska O, Cazzola S, Conidi A, Schellens A, van Dinther M, Stubbs A, Klippel A, Huylebroeck D, ten Dijke P, Verschueren K: Smad3 is a key nonredundant mediator of transforming growth factor beta signaling in Nme mouse mammary epithelial cells. Mol Cancer Res 2009, 7:1342-1353.

46. Dunn NR, Koonce CH, Anderson DC, Islam A, Bikoff EK, Robertson EJ: Mice exclusively expressing the short isoform of Smad2 develop normally and are viable and fertile. Genes Dev 2005, 19:152-163.

47. Chen CR, Kang Y, Massagué J: Defective repression of c-myc in breast cancer cells: A loss at the core of the transforming growth factor $\beta$ growth arrest program. Proc Natl Acad Sci U S A 2001, 98:992-999.

48. Ten Dijke P, Goumans MJ, Itoh F, Itoh S: Regulation of cell proliferation by Smad proteins. J Cell Physiol 2002, 191:1-16.

49. Levy L, Hill CS: Alterations in components of the TGF- $\beta$ superfamily signaling pathways in human cancer. Cytokine Growth Factor Rev 2006, 17:41-58.

50. Sjöblom T, Jones S, Wood LD, Parsons DW, Lin J, Barber TD, Mandelker D, Leary RJ, Ptak J, Silliman N, Szabo S, Buckhaults P, Farrell C, Meeh P, Markowitz SD, Willis J, Dawson D, Willson JK, Gazdar AF, Hartigan J, Wu L, Liu C, Parmigiani G, Park BH, Bachman KE, Papadopoulos N, Vogelstein B, Kinzler KW, Velculescu VE: The consensus coding sequences of human breast and colorectal cancers. Science 2006, 314:268-274.

51. Leary RJ, Lin JC, Cummins J, Boca S, Wood LD, Parsons DW, Jones S, Sjöblom T, Park BH, Parsons R, Willis J, Dawson D, Willson JK, Nikolskaya T, Nikolsky Y, Kopelovich L, Papadopoulos N, Pennacchio LA, Wang TL, Markowitz SD, Parmigiani G, Kinzler KW, Vogelstein B, Velculescu VE: Integrated analysis of homozygous deletions, focal amplifications, and sequence alterations in breast and colorectal cancers. Proc Natl Acad Sci U S A 2008, 105:16224-16229.

52. Dumont $N$, Arteaga $C L$ : Transforming growth factor $-\beta$ and breast cancer: Tumor promoting effects of transforming growth factor- $\beta$. Breast Cancer Res 2000, 2:125-132

53. Wakefield LM, Piek E, Bottinger EP: TGF-beta signaling in mammary gland development and tumorigenesis. J Mammary Gland Biol Neoplasia 2001, 6:67-82.

54. Gomis RR, Alarcon C, Nadal C, Van PC, Massagué J: C/EBP $\beta$ at the core of the TGF $\beta$ cytostatic response and its evasion in metastatic breast cancer cells. Cancer Cell 2006, 10:203-214.

55. Chittenden TW, Howe EA, Culhane AC, Sultana R, Taylor JM, Holmes C Quackenbush J: Functional classification analysis of somatically mutated genes in human breast and colorectal cancers. Genomics 2008, 91:508-511.

56. Siegel PM, Shu W, Cardiff RD, Muller WJ, Massagué J: Transforming growth factor beta signaling impairs Neu-induced mammary tumorigenesis while promoting pulmonary metastasis. Proc Natl Acad Sci U S A 2003, 100:8430-8435.

57. Tian F, DaCosta Byfield S, Parks WT, Yoo S, Felici A, Tang B, Piek E, Wakefield LM, Roberts AB: Reduction in Smad2/3 signaling enhances tumorigenesis but suppresses metastasis of breast cancer cell lines. Cancer Res 2003, 63:8284-8292

58. Roberts $A B$, Wakefield $L M$. The two faces of transforming growth factor beta in carcinogenesis. Proc Natl Acad Sci U S A 2003, 100:8621-8623.

59. Oft M, Peli J, Rudaz C, Schwarz H, Beug H, Reichmann E: TGF-beta1 and Ha-Ras collaborate in modulating the phenotypic plasticity and invasiveness of epithelial tumor cells. Genes Dev 1996, 10:2462-2477.

60. Janda E, Lehmann K, Killisch I, Jechlinger M, Herzig M, Downward J, Beug H, Grünert S: Ras and TGF[beta] cooperatively regulate epithelial cell plasticity and metastasis: dissection of Ras signaling pathways. J Cell Biol 2002, 156:299-313

61. Parvani JG, Taylor MA, Schiemann WP: Noncanonical TGF- $\beta$ signaling during mammary tumorigenesis. J Mammary Gland Biol Neoplasia 2011 , 16:127-146.

62. Adorno M, Cordenonsi M, Montagner M, Dupont S, Wong C, Hann B, Solari A, Bobisse S, Rondina MB, Guzzardo V Parenti AR, Rosato A, Bicciato S, Balmain A, Piccolo S: A Mutant-p53/Smad complex opposes p63 to empower TGFbeta-induced metastasis. Cell 2009, 137:87-98.

63. Wiercinska E, Naber HP, Pardali E, van der Pluijm G, van Dam H, Ten Dijke P: The TGF-beta/Smad pathway induces breast cancer cell invasion through the up-regulation of matrix metalloproteinase 2 and 9 in a spheroid 
invasion model system. Breast Cancer Res Treat 2010 Sep 5. [Epub ahead of print].

64. Nguyen DH, Martinez-Ruiz H, Barcellos-Hoff MH: Consequences of epithelial or stromal TGF $\beta 1$ depletion in the mammary gland. J Mammary Gland Biol Neoplasia 2011, 16:147-155

65. Barcellos-Hoff MH, Akhurst RJ: Transforming growth factor- $\beta$ in breast cancer: too much, too late. Breast Cancer Res 2009, 11:202-208.

66. Mani SA, Guo W, Liao MJ, Eaton EN, Ayyanan A, Zhou AY, Brooks M, Reinhard F, Zhang CC, Shipitsin M, Campbell LL, Polyak K, Brisken C, Yang J, Weinberg RA: The epithelial-mesenchymal transition generates cells with properties of stem cells. Cell 2008, 133:704-715.

67. Xu J, Lamouille S, Derynck R: TGF-beta-induced epithelial to mesenchymal transition Cell Res 2009, 19:156-172.

68. Fuxe J, Vincent T, Garcia de Herreros A: Transcriptional crosstalk between TGF $\beta$ and stem cell pathways in tumor cell invasion: role of EMT promoting Smad complexes. Cell Cycle 2010, 9:2363-2374.

69. Daly AC, Vizán P, Hill CS: Smad3 protein levels are modulated by Ras activity and during the cell cycle to dictate transforming growth factor-beta responses. J Biol Chem 2010, 285:6489-6497.

70. Han SU, Kim HT, Seong DH, Kim YS, Park YS, Bang YJ, Yang HK, Kim SJ: Loss of the $S m a d 3$ expression increases susceptibility to tumorigenicity in human gastric cancer. Oncogene 2004, 23:1333-1341.

71. Lamouille S, Derynck R: Cell size and invasion in TGF-beta-induced epithelial to mesenchymal transition is regulated by activation of the mTOR pathway. $\mathrm{I}$ Cell Bio/ 2007, 178:437-451.

72. Araki S, Eitel JA, Batuello CN, Bijangi-Vishehsaraei K, Xie XJ, Danielpour D, Pollok KE, Boothman DA, Mayo LD: TGF- $\beta 1$-induced expression of human $\mathrm{Mdm} 2$ correlates with late-stage metastatic breast cancer. $J$ Clin Invest 2010, 120:290-302.

73. Smith AP, Verrecchia A, Faga G, Doni M, Perna D, Martinato F, Guccione E, and Amati B: A positive role for Myc in TGF $\beta$-induced Snail transcription and epithelial-to-mesenchymal transition. Oncogene 2009, 28:422-430.

74. Gregory PA, Bracken CP, Smith E, Bert AG, Wright JA, Roslan S, Morris M, Wyatt L, Farshid G, Lim YY, Lindeman GJ, Shannon MF, Drew PA, Khew-Goodall Y, Goodall GJ: An autocrine TGF-beta/ZEB/miR-200 signaling network regulates establishment and maintenance of epithelial-mesenchymal transition. Mol Biol Cell 2011, 22:1686-1698.

75. Kong W, Yang H, He L, Zhao JJ, Coppola D, Dalton WS, Cheng JQ: MicroRNA-155 is regulated by the transforming growth factor beta/Smad pathway and contributes to epithelial cell plasticity by targeting RhoA. Mol Cell Biol 2008, 28:6773-6784.

76. Wang Y, Yu Y, Tsuyada A, Ren X, Wu X, Stubblefield K, Rankin-Gee EK, Wang SE: Transforming growth factor- $\beta$ regulates the sphere-initiating stem celllike feature in breast cancer through miRNA-181 and ATM. Oncogene 2011, 30:1470-1480

77. Papageorgis P, Lambert AW, Ozturk S, Gao F, Pan H, Manne U, Alekseyev YO, Thiagalingam A, Abdolmaleky HM, Lenburg M, Thiagalingam S: Smad signaling is required to maintain epigenetic silencing during breast cancer progression. Cancer Res 2010, 70:968-978.

78. Karnoub AE, Dash AB, Vo AP, Sullivan A, Brooks MW, Bell GW, Richardson AL, Polyak K, Tubo R, Weinberg RA: Mesenchymal stem cells within tumour stroma promote breast cancer metastasis. Nature 2007, 449:557-563.

79. Joshi A, Cao D: TGF-beta signaling, tumor microenvironment and tumor progression: the butterfly effect. Front Biosci 2010, 15:180-194.

80. Singha PK, Yeh IT, Venkatachalam MA, Saikumar P: Transforming growth factor-beta (TGF-beta)-inducible gene TMEPAI converts TGF-beta from a tumor suppressor to a tumor promoter in breast cancer. Cancer Res 2010, 70:6377-6383

81. Watanabe Y, Itoh S, Goto T, Ohnishi E, Inamitsu M, Itoh F, Satoh K, Wiercinska E, Yang W, Shi L, Tanaka A, Nakano N, Mommaas AM, Shibuya H, Ten Dijke P, Kato M: TMEPAI, a transmembrane TGF-beta-inducible protein, sequesters Smad proteins from active participation in TGF-beta signaling. Mol Cell 2010, 37:123-134

82. Alarmo EL, Kallioniemi A: Bone morphogenetic proteins in breast cancer: dual role in tumourigenesis? Endocr Relat Cancer 2010, 17:R123-139.

83. Buiis JT, Henriquez NV, van Overveld PG, van der Horst G, Que I, Schwaninger R, Rentsch C, Ten Dijke P, Cleton-Jansen AM, Driouch K, Lidereau R, Bachelier R, Vukicevic S, Clézardin P, Papapoulos SE, Cecchini MG, Löwik CW, van der Pluijm G: Bone morphogenetic protein 7 in the development and treatment of bone metastases from breast cancer. Cancer Res 2007, 67:8742-8751.

84. Naber HP, Wiercinska E, Pardali E, van Laar T, Nirmala E, Sundqvist A, van Dam $H$, van der Horst $G$, van der Pluijm G, Heckmann B, Danen EH, Ten Dijke P: BMP-7 inhibits TGF- $\beta$-induced invasion of breast cancer cells through inhibition of integrin $\beta$ (3) expression. Cell Oncol 2011, Sep 21. [Epub ahead of print].

85. Ketolainen JM, Alarmo EL, Tuominen VJ, Kallioniemi A: Parallel inhibition of cell growth and induction of cell migration and invasion in breast cancer cells by bone morphogenetic protein 4. Breast Cancer Res Treat 2010, 124:377-386.

86. Liu IM, Schilling SH, Knouse KA, Choy L, Derynck R, Wang XF: TGFbetastimulated Smad1/5 phosphorylation requires the ALK5 L45 loop and mediates the pro-migratory TGFbeta switch. EMBO J 2009, 28:88-98.

87. Giampieri S, Manning C, Hooper S, Jones L, Hill CS, Sahai E: Localized and reversible TGFbeta signalling switches breast cancer cells from cohesive to single cell motility. Nat Cell Bio/ 2009, 11:1287-1296.

88. Band AM, Laiho M: Crosstalk of TGF- $\beta$ and estrogen receptor signaling in breast cancer. J Mammary Gland Biol Neoplasia 2011, 16:109-115.

89. Deckers M, van Dinther M, Buiis J, Que I, Löwik C, van der Pluijm G, ten Dijke $P$ : The tumor suppressor Smad4 is required for transforming growth factor beta-induced epithelial to mesenchymal transition and bone metastasis of breast cancer cells. Cancer Res 2006, 66:2202-2209.

90. Korpal M, Yan J, Lu X, Xu S, Lerit DA, Kang Y: Imaging transforming growth factor-beta signaling dynamics and therapeutic response in breast cancer bone metastasis. Nat Med 2009, 15:960-966.

91. Petersen M, Pardali E, van der Horst G, Cheung H, van den Hoogen C, van der Pluijm G, Ten Dijke P. Smad2 and Smad3 have opposing roles in breast cancer bone metastasis by differentially affecting tumor angiogenesis. Oncogene 2010, 29:1351-1361.

92. Le Scolan E, Zhu Q, Wang L, Bandyopadhyay A, Javelaud D, Mauviel A, Sun L, Luo K: Transforming growth factor-beta suppresses the ability of Ski to inhibit tumor metastasis by inducing its degradation. Cancer Res 2008, 68:3277-3285

93. Wilson CA, Cajulis EE, Green JL, Olsen TM, Chung YA, Damore MA, Dering J, Calzone FJ, Slamon DJ: HER-2 overexpression differentially alters transforming growth factor-beta responses in luminal versus mesenchymal human breast cancer cells. Breast Cancer Res 2005, 7:R1058-1079.

94. Arnal-Estapé A, Tarragona M, Morales M, Guiu M, Nadal C, Massagué J, Gomis RR: HER2 silences tumor suppression in breast cancer cells by switching expression of C/EBP\{beta\} isoforms. Cancer Res 2010, 70:9927-9936.

95. de Graauw M, van Miltenburg MH, Schmidt MK, Pont C, Lalai R, Kartopawiro J, Pardali E, Le Dévédec SE, Smit VT, van der Wal A, Van't Veer LJ, Cleton-Jansen AM, ten Dijke P, van de Water B: Annexin A1 regulates TGF-beta signaling and promotes metastasis formation of basal-like breast cancer cells. Proc Natl Acad Sci U S A 2010, 107:6340-6345.

96. Verrecchia F, Tacheau C, Schorpp-Kistner M, Angel P, Mauviel A: Induction of the AP-1 members c-Jun and JunB by TGF-beta/Smad suppresses early Smad-driven gene activation. Oncogene 2001, 20:2205-2211.

97. Hua X, Liu X, Ansari DO, Lodish HF: Synergistic cooperation of TFE3 and smad proteins in TGF-beta-induced transcription of the plasminogen activator inhibitor-1 gene. Genes Dev 1998, 12:3084-3095.

98. Luo K, Stroschein SL, Wang W, Chen D, Martens E, Zhou S, Zhou Q: The Ski oncoprotein interacts with the Smad proteins to repress TGFbeta signaling. Genes Dev 1999, 13:2196-2206.

99. Janknecht R, Wells NJ, Hunter T: TGF-beta-stimulated cooperation of smad proteins with the coactivators CBP/p300. Genes Dev 1998, 12:2114-2119.

100. Dai F, Duan $X$, Liang YY, Lin X, Feng XH: Coupling of dephosphorylation and nuclear export of Smads in TGF-beta signaling. Methods Mol Biol 2010, 647:125-137

\section{doi:10.1186/bcr3066}

Cite this article as: Sundqvist A, et al:: Key signaling nodes in mammary gland development and cancer: Smad signal integration in epithelial cell plasticity. Breast Cancer Research 2012, 14:204. 